\title{
Evaluation of optimal storage time of tuberculous lesions stored in sodium borate
}

\author{
Avaliação do tempo de armazenamento do borato de sódio na \\ conservação de lesões tuberculosas
}

\author{
Flávia Morato ${ }^{1}$; Cássia Yumi Ikuta ${ }^{1 *}$; Amane Paldês Gonçales ${ }^{2}$; \\ Gisele Oliveira de Souza'; Marcos Amaku³ ${ }^{3}$ Adriana Cortez ${ }^{2}$; \\ Marcos Bryan Heinemann ${ }^{4}$ José Soares Ferreira Neto ${ }^{4}$
}

\begin{abstract}
Preservation of specimens during transportation between abattoirs and diagnostic laboratories defines a critical stage in the definitive diagnosis of bovine tuberculosis by the isolation of Mycobacterium bovis. A 2-step study was designed to verify the maximum time that tissue samples can be stored in saturated sodium borate solution (SSB) with the highest detection of $M$. bovis isolates. Ninety hamsters were inoculated intraperitoneally with a suspension of M. bovis strain AN5 and were humanely euthanized after 40 days. Their spleens were collected and stored in SSB during four distinct periods $(30,60,90$ and 120 days) with incubation at two temperatures $\left(27^{\circ} \mathrm{C}\right.$ and $\left.37^{\circ} \mathrm{C}\right)$. The control group was cultured on the day of euthanasia. Sixty-nine suspected tuberculous lesions samples were collected in the abattoir and were stored in SSB for three periods $\left(30,60\right.$ and 90 days) at $27^{\circ} \mathrm{C}$ in the laboratory. The bovine control group was cultured on the day of entry in the laboratory. Both experiments were analyzed separately based on the growth proportion of isolates and the number of colonies. SSB was able to maintain the viability of most $M$. bovis at high temperatures for up to 30 days. A progressive decline was observed with other storage periods at $27^{\circ} \mathrm{C}$, and no growth was obtained after 60 -day storage at $37^{\circ} \mathrm{C}$. Despite the loss in viability of $M$. bovis, SSB is the most favorable choice to preserve specimens during transportation across a large country with high variation in environmental temperature. The sensitivity of $M$. bovis detection by bacteriological examination is inversely proportional to storage time. Therefore, the storage of tuberculous lesion specimens in SSB is recommended to not exceed 30 days at $27^{\circ} \mathrm{C}$ before cultivation.
\end{abstract}

Key words: Bovine tuberculosis. Mycobacterium bovis. Preservative. Sodium borate. Transportation.

\section{Resumo}

A conservação de espécimes durante o transporte entre abatedouros e laboratórios de diagnóstico define uma etapa crítica no diagnóstico definitivo da tuberculose bovina pelo isolamento de Mycobacterium bovis. Um estudo de duas fases foi delineado para verificar o tempo máximo de armazenamento que amostras teciduais podem ser mantidas em solução saturada de borato de sódio (SSB) com a mais alta detecção de isolados de M. bovis. Noventa hamsters foram inoculados com suspensão de M. bovis

\footnotetext{
${ }^{1}$ Pesquisadores, Faculdade de Medicina Veterinária e Zootecnia, Universidade de São Paulo, USP, São Paulo, SP, Brasil. E-mail: flamorato@usp.br; cassiayi@yahoo.com.br; ginutri@usp.br

${ }^{2}$ Profs., Curso de Medicina Veterinária, Universidade de Santo Amaro, UNISA, São Paulo, SP, Brasil. E-mail: apgoncales@unisa. br; acortez@unisa.br

${ }^{3}$ Prof., Faculdade de Medicina, USP, São Paulo, SP, Brasil. E-mail: amaku@vps.fmvz.usp.br

${ }^{4}$ Profs., Faculdade de Medicina Veterinária e Zootecnia, USP, São Paulo, SP, Brasil. E-mail: marcosbryan@usp.br; jsoares@vps. fmvz.usp.br

* Author for correspondence
} 
cepa AN5 por via intraperitoneal e, após 40 dias, submetidos à eutanásia humanitária. Os baços foram coletados, armazenados em SSB por quatro períodos distintos (30, 60, 90 e 120 dias) e incubados a duas temperaturas $\left(27\right.$ e $\left.37^{\circ} \mathrm{C}\right)$. O grupo controle foi cultivado no mesmo dia da eutanásia. Sessenta e nove amostras de lesões suspeitas de tuberculose foram coletadas em abatedouro e armazenadas em SSB por três períodos (30, 60 e 90 dias) a $27^{\circ} \mathrm{C}$ no laboratório. O grupo controle bovino foi cultivado no dia da entrada no laboratório. Ambos os experimentos foram analisados separadamente baseados na proporção de crescimento de isolados e no número de colônias. A SSB foi capaz de manter a maioria de M. bovis viáveis em altas temperaturas por até 30 dias. Houve um declínio progressivo nos outros períodos de armazenamento a $27^{\circ} \mathrm{C}$, e não houve crescimento a partir de 60 dias a $37^{\circ} \mathrm{C}$. Apesar da perda de viabilidade de $M$. bovis, a SSB é a escolha mais favorável para preservar as amostras durante o transporte em um grande país com alta variação de temperatura ambiente. A sensibilidade de detecção de $M$. bovis por exames bacteriológicos é inversamente proporcional ao tempo de armazenamento. Portanto, é recomendado que o armazenamento de amostras de lesões tuberculosas em SSB não exceda 30 dias a $27^{\circ} \mathrm{C}$ antes do cultivo.

Palavras-chave: Tuberculose bovina. Mycobacterium bovis. Conservante. Borato de sódio. Transporte.

\section{Introduction}

Bovine tuberculosis is a well-known chronic zoonosis caused by Mycobacterium bovis. This disease is responsible for elevated economic losses and public health issues. In Brazil, recent studies carried out in 13 states that hold $75 \%$ of the Brazilian cattle population, showed the prevalence of tuberculosis-infected herds among $0.36 \%$ in the Federal District and 9\% in São Paulo (BAHIENSE et al., 2016; BARBIERI et al., 2016; DIAS et al., 2016; GALVIS et al., 2016; GUEDES et al., 2016; LIMA et al., 2016; NÉSPOLI et al., 2016; QUEIROZ et al., 2016; RIBEIRO et al., 2016; ROCHA et al., 2016; SILVA et al., 2016; VELOSO et al., 2016; VENDRAME et al., 2016). Thus, the success of the Program of Control and Eradication of Brucellosis and Tuberculosis relies on the surveillance system based on the isolation of $M$. bovis from suspected tuberculous lesions obtained from abattoirs (LAGE et al., 2006).

Bacteriological examination is required for the definitive diagnosis, given that traditional culture remains the gold standard method for infection routine confirmation (OIE, 2009). Culture media, decontamination procedures and incubation conditions have direct impact on the primary isolation of M. bovis (CORNER, 1994). Molecular techniques have also assisted detection and identification of this infectious agent (SALES et al., 2014a, 2014b).
Nevertheless, the preservation of tissue and lesion samples during transportation between abattoirs and diagnostic laboratories defines a critical stage that precedes all other procedures. The number of viable mycobacteria can decrease when specimens are handled inadequately (WARDS et al., 1995).

Immediate delivery of samples to the laboratory enhances the chances of $M$. bovis recovery. If the collected samples are cultured within 24 to 48 hours, they should be maintained between $4^{\circ} \mathrm{C}$ to $6^{\circ} \mathrm{C}$. If this period is exceeded, specimens must be stored frozen until be thawed for cultivation (CORNER, 1994; OIE, 2009).

Brazil has a high diversity of warm environmental conditions, infrastructural availability and large distances from abattoir to laboratory, thus the use of preservative agents are required to overcome these issues. Chemical agents, such sodium carbonate, cetylpyridinium chloride (BOBADILLA-DELVALLE et al., 2003), chloramine-T (sodium $p$-toluenesulfonchloramide) and sodium borate (RICHARDS; WRIGHT, 1983), have been assayed for preserving mycobacteria and delaying the growth of contaminants.

Sodium borate is the most recommended (RICHARDS; WRIGHT, 1983; OIE, 2009) and employed preservative in routine abattoir inspection (CORNER, 1994; BROWN; HERNÁNDEZ DE ANDA, 1998; MILIÁN et al., 2000; MILLER et 
al, 2002; RODRIGUEZ et al., 2004; THACKER et al., 2013). Although the final concentration of sodium borate varies from $0.5 \%$ (OIE, 2009) and 6\% (MILIÁN et al., 2000) to a saturated solution (RICHARDS; WRIGHT, 1983; CORNER, 1994), the latter is more widely applied (BROWN; HERNÁNDEZ DE ANDA, 1998; MILLER et al., 2002; RODRIGUEZ et al., 2004; THACKER et al., 2013).

Due to the range of environmental temperature in the country and the demand for well-preserved specimens, the aim of the present study is to verify the maximum time that tissue samples can be stored in saturated sodium borate solution (SSB) with the highest detection of M. bovis isolates.

\section{Material and Methods}

The study was performed in two steps. The first step was based on experimental infection in animal models to produce standard lesions. The second step consisted of a trial with lesion samples collected from an abattoir.

\section{Tissue samples}

Experimental infection in Hamsters (Mesocricetus auratus)

The present study was carried out in accordance with ethical and biosafety regulations, and was certified by the "Ethic Committee in the use of animals" of the School of Veterinary Medicine and Animal Science of the University of São Paulo (protocol number 1415/2008).

Ninety male hamsters, weighing between 70 and 160 grams, were housed on wood-shavings bedding with commercial food and water provided ad libitum. Mycobacterium bovis strain AN5 colonies were grown in Middlebrook 7H9 broth (according to the manufacturer's instructions; Becton, Dickinson and Company, Sparks, MD, USA) and the suspension was adjusted to match the
$0.5 \mathrm{McF}$ arland turbidity standard by adding sterile $0.85 \%$ saline solution. Through culturing tenfold dilutions on Stonebrink medium, colony forming units (CFU) score at 30 days of incubation was used to establish the suspension chosen for inoculation. Each animal received 3,000 CFU intraperitoneally.

After 40 days, all animals were humanely euthanized. The spleens were collected and stored in non-sterile glass vials containing $25 \mathrm{~mL} \mathrm{SSB}$ $\left(\mathrm{Na}_{2} \mathrm{~B}_{4} \mathrm{O}_{7} \cdot 10 \mathrm{H}_{2} \mathrm{O}, 14 \mathrm{~g}\right.$ in $100 \mathrm{~mL}$ of distilled water, RODRIGUEZ et al., 2004). Forty specimens were incubated at $27^{\circ} \mathrm{C}$ and 40 , at $37^{\circ} \mathrm{C}$.

Ten specimens were used as control group and were freshly cultured on the day of euthanasia determining day zero (D.0). Of the specimens stored in SSB, ten spleens from each temperature were cultured after 30 (D.30), 60 (D.60), 90 (D.90) and 120 (D.120) days of incubation.

\section{Bovine samples from abattoir}

Sixty-nine suspected tuberculous lesions samples were collected from an abattoir. These included 29 lymph nodes, 23 lungs, 13 livers, 3 muscles and 1 heart. In the abattoir, the samples were placed in $500 \mathrm{~mL}$ plastic flasks and were immersed in SSB to be transported to the laboratory, where they were incubated at $27^{\circ} \mathrm{C}$.

Samples were cultured after 5 (D.5), 30 (D.30), 60 (D.60) and 90 (D.90) days from collection. Given the impossibility of culturing the fresh specimens, D.5 was considered as the control group.

\section{Cultivation}

For culture, the whole spleen was used in the first step and one gram of each specimen was used in the second. The tissue was macerated in $5 \mathrm{~mL}$ sterile $0.85 \%$ saline solution using the Stomacher ${ }^{\circledR}$ 80 Biomaster (Seward, Port Saint Lucie, Florida, USA). The suspension was decontaminated with $0.75 \%$ 1-hexadecylpyridinium chloride at 
room temperature (RT) for 20 minutes, and then centrifuged at $2,300 \times g$ for 20 minutes (AMBROSIO et al., 2008). The supernatant was discarded and the sediment was resuspended in $1 \mathrm{~mL}$ sterile $0.85 \%$ saline solution. Each suspension was inoculated into duplicate slopes of Stonebrink medium in a volume of $0.1 \mathrm{~mL}$, and incubated at $37^{\circ} \mathrm{C}$ (CENTRO PANAMERICANO DE ZOONOSES, 1973).

The slopes were examined for growth every seven days. The CFU counts were scored at 90 days of incubation (OIE, 2009). For analysis, the average number of colonies from the two slopes was calculated. The total of 300 colonies was adopted when the number of colonies was too large to be counted (BRASIL, 1993).

\section{Molecular identification}

The isolates were identified by PCR-restriction fragment length polymorphism analysis (PRA) of the hsp65 gene (TELENTI et al., 1993) and a multiplex PCR method based on the genomic regions of difference (RD) (WARREN et al., 2006).

\section{Statistical analysis}

The growth proportion of M. bovis isolates was analyzed using comparison of proportions test. The number of CFUs from hamster spleens (in D.0, D.30, D.60, D.90 and D.120) was analyzed using the Kruskal-Wallis' test, and the Dunn's test was used for multiple comparisons. The number of CFU from bovine specimens (in D.5, D.30, D.60 and D. 90 ) and the time of incubation in SSB were analyzed using the Friedman's test, and the Dunn's test was used for multiple comparisons. Differences were considered as statistically significant at $p<0.05$. The comparisons were performed using the computer programs Minitab 16 and GraphPad Instat.

\section{Results}

Experimental infection in hamsters (Mesocricetus auratus)

At the time of necropsy, the experimentally infected animals presented prostration and stubbly hair. The spleens were enlarged with yellow punctiform lesions on their surface. The morphological aspects of the isolates were identical to those of the M. bovis strain AN5. There was no growth in specimens cultured on D.60, D.90 and D. 120 at $37^{\circ} \mathrm{C}$.

No difference was observed between D.0 and D.30, or D.60, D.90 and D.120 on the growth proportion of isolates, at both temperatures $(p>0.05)$. At $27^{\circ} \mathrm{C}, \mathrm{D} .0$ and D.30 samples showed more isolates than D.60 $(p=0.015), D .90$ and D. $120(p=0.0003)$. On the other hand, at $37^{\circ} \mathrm{C}, \mathrm{D} .0$ displayed better detection $(p=0.0001)$ than D.30 $(p=0.005)$, when compared to the other storage times. The median CFU number of D.0 was higher than D.30 at $27^{\circ} \mathrm{C}$, but not significantly different. Table 1 shows the growth proportion of M. bovis and the mean and median CFU numbers.

Table 1. Growth proportion of $M$. bovis strain AN5 isolates, median and mean of CFU numbers from hamster spleens according to the days of storage in SSB and the incubation temperatures.

\begin{tabular}{lccccccccc}
\hline Storage time (days) & D.0 & \multicolumn{2}{c}{ D.30 } & \multicolumn{2}{c}{ D.60 } & \multicolumn{2}{c}{ D.90 } & \multicolumn{2}{c}{ D. 120} \\
\hline Incubation temperature & - & $27^{\circ} \mathrm{C}$ & $37^{\circ} \mathrm{C}$ & $27^{\circ} \mathrm{C}$ & $37^{\circ} \mathrm{C}$ & $27^{\circ} \mathrm{C}$ & $37^{\circ} \mathrm{C}$ & $27^{\circ} \mathrm{C}$ & $37^{\circ} \mathrm{C}$ \\
M. bovis isolates (\%) & $100^{\mathrm{a}}$ & $100^{\mathrm{a}}$ & $70^{\mathrm{a}}$ & $40^{\mathrm{b}}$ & $0^{\mathrm{b}}$ & $10^{\mathrm{b}}$ & $0^{\mathrm{b}}$ & $10^{\mathrm{b}}$ & $0^{\mathrm{b}}$ \\
CFU median & $300^{\mathrm{a}}$ & $300^{\mathrm{a}}$ & 115 & $109^{\mathrm{b}}$ & 8 & $0^{\mathrm{b}}$ & 0 & $0^{\mathrm{b}}$ & 0 \\
CFU mean & 300 & 147,4 & 47,7 & 10,9 & 0 & 5 & 0 & 20 & 0 \\
\hline
\end{tabular}

a, b different letters mean statistical difference. 


\section{Bovine samples from abattoir}

From the results of experimental infection in hamsters, bovine samples were subjected to the suitable SSB storage time and incubation temperature.

The specimens were immersed in SSB for the maximum of 5 days when they arrived at the laboratory. Almost every collected tissue presented enlargement and yellow round shaped tuberculouslike lesions. Caseous lesions replacing almost the entire tissue were also observed in some specimens.
The isolates that showed morphological aspects compatible with mycobacteria were classified as member of the $M$. tuberculosis complex by PRA and were identified as $M$. bovis by the RD multiplex PCR method.

Along the advance of each storage time, the growth proportion of isolates decreased $(p<0.001)$ along with the CFU number ( $p<0.001)$, except the CFU at D.60 and D.90 ( $>00.05)$. Table 2 presents the growth proportion of $M$. bovis and the median and mean of the CFU number.

Table 2. Growth proportion of $M$. bovis isolates, median and mean of CFU numbers from bovine samples incubated at $27^{\circ} \mathrm{C}$ according to the days of storage in SSB.

\begin{tabular}{lcccc}
\hline Storage time (days) & D.5 & D.30 & D.60 & D.90 \\
\hline$M$. bovis growth (\%) & $100^{\mathrm{a}}$ & $82,6^{\mathrm{b}}$ & $26,1^{\mathrm{c}}$ & $3^{\mathrm{d}}$ \\
CFU median & $115^{\mathrm{a}}$ & $8^{\mathrm{b}}$ & $0^{\mathrm{c}}$ & $0^{\mathrm{c}}$ \\
CFU mean & 136,9 & 44,9 & 1,6 & 0,1 \\
\hline
\end{tabular}

a, b, c, d different letters mean statistical difference.

\section{Discussion}

Preservation of suspected tuberculous lesions is directly related to the success of $M$. bovis detection. Maintenance of viable mycobacteria and inhibition of contaminants are important desirable factors in a preservative agent.

SSB has been used in routine procedures in Australia, where the environmental temperature can reach $40^{\circ} \mathrm{C}$ (CORNER, 1994). Similar climatic conditions can be observed in Brazil. In order to refine the storage conditions in a controlled environment, hamsters were used as biological models to obtain standardized tuberculous lesions.

The present study showed a decline in the growth of isolates and in the CFU number when the temperature increased from $27^{\circ} \mathrm{C}$ to $37^{\circ} \mathrm{C}$, and when the storage time in SSB was extended. In both trials, the results from both hamster and bovine samples mostly suffered from 30 to 60 days of storage.

According to OIE (2009), boric acid in low concentrations can be used as a bacteriostatic agent, but only for limited periods, and no longer than one week. Milián et al. (2000) observed that $6 \%$ sodium borate solution was able to not interfere with $M$. bovis diagnosis of bovine lesions that were stored for up to 150 days at RT from $25^{\circ} \mathrm{C}$ to $35^{\circ} \mathrm{C}$, even though the CFU number decreased by $98 \%$ from 30 -day to 150 -day storage.

Richards and Wright (1983) analyzed bovine specimens stored in SSB at RT (approximately $23^{\circ} \mathrm{C}$ ) and observed no isolation after 14 weeks of storage (98 days), nor over 24 weeks of storage (168 days). Nevertheless, $M$. bovis was isolated from one specimen stored for 17 weeks (119 days) and from all nine specimens stored for 8 weeks (56 days) or less.

When the specimen presents high quantities of mycobacteria, the concentration of the sodium borate solution and the storage temperature might not affect $M$. bovis detection. However, if the number of viable mycobacteria is low, it may display in false-negative results. 
The type of specimen preserved in SSB also plays an important role in terms of maintaining mycobacteria viability, since it determines the proximity of the bacteria to the preservative solution. An in vitro evaluation of preservatives that were in direct contact with culture suspensions showed that exposure to SSB for 7 days at $23^{\circ} \mathrm{C}$ or $\mathrm{RT}$, displayed a discrete reduction in the number of viable $M$. bovis cells (RICHARDS; WRIGHT, 1983). Through constant temperature, the storage of hamster spleens in SSB at $27^{\circ} \mathrm{C}$ and $37^{\circ} \mathrm{C}$ for 150 days was harmful to $M$. bovis survival (MORATO ${ }^{5}$; unpublished data).

No growth of contaminants was observed in the present study, while Richards and Wright (1983) needed to reculture $6.1 \%$ of the specimens due to contamination issues.

Despite the increased loss in viability of $M$. bovis in sodium borate rather than upon chilling at $4-6^{\circ} \mathrm{C}$ (RICHARDS; WRIGHT, 1983; CORNER, 1994) and the decrease in growth of isolates, immersion in SSB is the most favorable choice to preserve specimens during transportation in a large country with high environmental temperature variation.

\section{Conclusions}

The storage of tuberculous lesion specimens in SSB is recommended to not exceed 30 days at $27^{\circ} \mathrm{C}$ before cultivation. The shorter the time they are maintained in preservative agents, the lower will be the sensitivity loss of $M$. bovis detection by bacteriological exams, which are an important part of the surveillance system in Brazil.

\section{Acknowledgements}

The authors acknowledge the financial support from CAPES, CNPq and FAPESP.

5 MORATO, F. unpublished data obtained in October, 2010.

\section{References}

AMBROSIO, S. R.; OLIVEIRA, E. M. D.; RODRIGUEZ, C. A. R.; FERREIRA NETO, J. S.; AMAKU, M. Comparison of three decontamination methods for Mycobacterium bovis isolation. Brazilian Journal of Microbiology, Rio de Janeiro, v. 39, n. 2, p. 241-244, 2008.

BAHIENSE, L.; ÁVILA, L. N. de; BAVIA, M. E.; AMAKU, M.; DIAS, R. A.; GRISI-FILHO, J. H. H.; FERREIRA, F.; TELLES, E. O.; GONÇALVES, V. S. P.; HEINEMANN, M. B.; FERREIRA NETO, J. S. Prevalence and risk factors for bovine tuberculosis in the State of Bahia, Brazil. Semina: Ciências Agrárias, Londrina, v. 37, n. 5, p. 3549-3560, 2016. Suplemento 2.

BARBIERI, J. M.; OLIVEIRA, L. F.; DORNELES, E. M. S.; MOTA, A. L. A. A.; GONÇALVES, V. S. P.; MALUF, P. P.; FERREIRA NETO, J. S.; FERREIRA, F.; DIAS, R. A.; TELLES, E. O.; GRISI-FILHO, J. H. H.; HEINEMANN, M. B.; AMAKU, M.; LAGE, A. P. Epidemiological status of bovine tuberculosis in the state of Minas Gerais, Brazil, 2013. Semina: Ciências Agrárias, Londrina, v. 37, n. 5, p. 3531-3548, 2016. Suplemento 2.

BOBADILLA-DEL-VALLE, M.; PONCE-DE-LEÓN, A.; KATO-MAEDA, M.; HERNÁNDEZ-CRUZ, A.; CALVA-MERCADO, J. J.; CHÁVEZ-MAZARI, B.; CABALLERO-RIVERA, B. A.; NOLASCO-GARCÍA, J. C.; SIFUENTES-OSORNIO, J. Comparison of sodium carbonate, cetyl-pyridinium chloride, and sodium borate for preservation of sputa for culture of Mycobacterium tuberculosis. Journal of Clinical Microbiology, Washington, v. 41, n. 9, p. 4487-4488, 2003.

BRASIL. Ministério da Agricultura, do Abastecimento e da Reforma Agrária. Secretaria Nacional de Defesa Agropecuária. Departamento Nacional de Defesa Animal - LANARA. Métodos de análise microbiológica para alimentos. 1991/1992. 2. rev. Brasília: LANARA, 1993. $136 \mathrm{p}$.

BROWN, W.; HERNÁNDEZ DE ANDA, J. Tuberculosis in adult beef cattle of Mexican origin shipped direct-toslaughter into Texas. Journal of the American Veterinary Medical Association, Schaumburg, v. 212, n. 4, p. $557-$ 559, 1998.

CENTRO PANAMERICANO DE ZOONOSIS CEPANZO. Metodos de laboratorio de micobacteriologia veterinaria para el aislamiento e identicacion de micobacterias. Buenos Aires: CPZ, 1973. 48 p. (Série de monografias cientificas y tecnicas, 6).

CORNER, L.A. Post mortem diagnosis of Mycobacterium bovis infection in cattle. Veterinary Microbiology, Amsterdam, v. 40, n. 1-2, p. 53-63, 1994. 
DIAS, R. A.; STANOJLOVIC, F. M. U.; BELCHIOR, A. P. C.; FERREIRA, R. S.; GONÇALVES, R. C.; AGUIAR, R. S. C. B.; SOUSA, P. R.; SANTOS, A. M. A.; AMAKU, M.; FERREIRA, F.; TELLES, E. O.; GRISI-FILHO, J. H. H.; GONÇALVES, V. S. P.; HEINEMANN, M. B.; FERREIRA NETO, J. S. Prevalence and risk factors for bovine tuberculosis in the state of São Paulo, Brazil. Semina: Ciências Agrárias, Londrina, v. 37, n. 5, p. 3673-3684, 2016. Suplemento 2.

GALVIS, J. O. A.; GRISI-FILHO, J. H. H; COSTA, D.; SAID, A. L. P. R.; AMAKU, M.; DIAS, R. A.; FERREIRA, F.; GONÇALVES, V. S. P.; HEINEMANN, M. B.; TELlES, E. O.; FERREIRA NETO, J. S. Epidemiologic characterization of bovine tuberculosis in the state of Espírito Santo, Brazil. Semina: Ciências Agrárias, Londrina, v. 37, n. 5, p. 3567-3578, 2016. Suplemento 2.

GUEDES, I. B.; BOTTENE, I. F. N.; MONTEIRO, L. A. R. C.; LEAL FILHO, J. M.; HEINEMANN, M. B.; AMAKU, M.; GRISI-FILHO, J. H. H.; DIAS, R. A.; FERREIRA, F.; TELLES, E. O.; GONÇALVES, V. S. P.; FERREIRA NETO, J. S. Prevalence and risk factors for bovine tuberculosis in the state of Mato Grosso do Sul, Brazil. Semina: Ciências Agrárias, Londrina, v. 37, n. 5, p. 3579-3588, 2016. Suplemento 2.

LAGE, A. P.; ROXO, E.; MÜLlER, E.; POESTER, F.; CAVALLÉRO, J. C. M.; FERREIRA NETO, J. S.; MOTA, P. M. P. C.; GONÇALVES, V. S. P. Programa nacional de controle e erradicação da brucelose e da tuberculose animal (PNCEBT). Brasília: Ministério da Agricultura, Pecuária e Abastecimento, 2006, 184 p. (Manual técnico).

LIMA, P. B.; NASCIMENTO, D. L.; ALMEIDA, E. C.; PONTUAL, K. A. Q.; AMAKU, M.; DIAS, R. A.; FERREIRA, F.; GONÇALVES, V. S. P.; TELLES, E. O.; GRISI-FILHO, J. H. H.; HEINEMANN, M. B.; SILVA, J. C. R.; FERREIRA NETO, J. S. Epidemiological situation of bovine tuberculosis in the state of Pernambuco, Brazil. Semina: Ciências Agrárias, Londrina, v. 37, n. 5, p. 3601-3610, 2016. Suplemento 2.

MILIÁN, F.; SÁNCHEZ, L. M.; TOLEDO, T.; RAMÍREZ, C.; SANTILLÁN, M. A. Descriptive study of human and bovine tuberculosis in Querétaro, México. Revista Latinoamericana de Microbiologia, México, v. 42, n. 1, p. 13-19, 2000.

MILLER, J. M.; JENNY, A. L.; PAYEUR, J. B. Polymerase chain reaction detection of Mycobacterium tuberculosis complex and Mycobacterium avium organisms in formalin-fixed tissues from culture-negative ruminants. Veterinary Microbiology, Amsterdam, v. 87, n. 1, p. 15-23, 2002.
NÉSPOLI, J. M. B.; NEGREIROS, R. L.; AMAKU, M.; DIAS, R. A.; FERREIRA, F.; TELLES, E. O.; HEINEMANN, M. B.; GRISI-FILHO, J. H. H.; GONÇALVES, V. S. P.; FERREIRA NETO, J. S. Epidemiological situation of bovine tuberculosis in the state of Mato Grosso, Brazil. Semina: Ciências Agrárias, Londrina, v. 37, n. 5, p. 3589-3600, 2016. Suplemento 2.

QUEIROZ, M. R.; GROFF, A. C. M.; SILVA, N. S.; GRISI-FILHO, J. H. H.; AMAKU, M.; DIAS, R. A.; TELLES, E. O.; HEINEMANN, M. B.; FERREIRA NETO, J. S.; GONÇALVES, V. S. P. FERREIRA, F. Epidemiological status of bovine tuberculosis in the state of Rio Grande do Sul, Brazil. Semina: Ciências Agrárias, Londrina, v. 37, n. 5, p. 3647-3658, 2016. Suplemento 2.

RIBEIRO, L. A.; GONÇALVES, V. S. P.; FRANCISCO, P. F. C.; MOTA, A. L. A. A.; NASCIMENTO, G. T.; LICURGO, J. B.; FERREIRA, F.; GRISI-FILHO, J. H. H.; FERREIRA NETO, J. S.; AMAKU, M.; DIAS, R. A.; TELLES, E. O.; HEINEMANN, M. B.; BORGES, J. R. J. Epidemiological status of bovine tuberculosis in the Federal District of Brazil. Semina: Ciências Agrárias, Londrina, v. 37, n. 5, p. 3561-3566, 2016. Suplemento 2.

RICHARDS, W. D.; WRIGHT, H. S. Preservation of tissue specimens during transport to mycobacteriology laboratories. Journal of Clinical Microbiology, Washington, v. 17, n. 3, p. 393-395, 1983.

ROCHA, W. V.; JAYME, V. S.; MOTA, A. L. A. A.; BRITO, W. M. E. D; PIRES, G. R. C; GRISI-FILHO, J. H. H; DIAS, R. A.; AMAKU, M.; TELLES, E. O.; HEINEMANN, M. B.; FERREIRA, F.; FERREIRA NETO, J. S.; GONÇALVES, V. S. P. Prevalence and herd-level risk factors of bovine tuberculosis in the State of Goiás, Brazil. Semina: Ciências Agrárias, Londrina, v. 37, n. 5, p. 3625-3628, 2016. Suplemento 2.

RODRIGUEZ, C. A. R.; ZUMÁRRAGA, M. J.; OLIVEIRA, E. M. de D.; CATALDI, A. A.; ROMANO, M. I.; OTTO, H. H.; BONAFÉ, V. I.; FERREIRA NETO, J. S. Caracterização molecular de isolados de Mycobacterium bovis do Estado de São Paulo Brasil, utilizando a técnica de spoligotyping. Arquivos do Instituto Biológico, São Paulo, v. 71, n. 3, p. 277-282, 2004.

SALES, M. L.; FONSECA JÚNIOR, A. A.; ORZIL, L.; ALENCAR, A. P.; HODON, M. A.; ISSA, M. A.; SOARES FILHO, P. M.; SILVA, M. R.; LAGE, A. P.; HEINEMANN, M. B. Validation of two real-time PCRs targeting the PE-PGRS 20 gene and the region of difference 4 for the characterization of Mycobacterium bovis isolates. Genetics and Molecular Research, Ribeirao Preto, v. 13, n. 2, p. 4607-4616, 2014 a. 
SALES, M. L.; FONSECA JÚNIOR, A. A.; SALES, E. B.; COTTORELLO, A. C. P.; ISSA, M. A.; HODON, M. A.; SOARES FILHO, P. M.; RAMALHO, A. K.; SILVA, M. R.; LAGE, A. P.; HEINEMANN, M. B. Evaluation of molecular markers for the diagnosis of Mycobacterium bovis. Folia Microbiologica, Praha, v. 59, n. 5, p. 433438, 2014b.

SILVA, M. C. P.; GONÇALVES, V. S. P.; MOTA, A. L. A. A.; KOLODA, M.; FERREIRA NETO, J. S.; GRISIFILHO, J. H. H; DIAS, R. A.; AMAKU, M.; TELLES, E. O.; FERREIRA, F.; HEINEMANN, M. B.; ALFIERI, A. A.; MULLER, E. E. Prevalence and herd-level risk factors for bovine tuberculosis in the state of Paraná, Brazil. Semina: Ciências Agrárias, Londrina, v. 37, n. 5, p. 3611-3624, 2016. Suplemento 2.

TELENTI, A.; MARCHESI, F.; BALZ, M.; BALLY, F.; BOTTGER, B. T. Rapid identification of mycobacteria to the species level by polymerase chain reaction and restriction enzyme analysis. Journal of Clinical Microbiology, Washington, v. 31, n. 2, p. 175-178, 1993.

THACKER, T. C.; ROBBE-AUSTERMAN, S.; HARRIS, B.; VAN PALMER, M.; WATERS, W. R. Isolation of mycobacteria from clinical samples collected in the United States from 2004 to 2011. BMC Veterinary Research, London, v. 9, id 100, 2013.

VELOSO, F. P.; BAUMGARTEN, K. D.; MOTA, A. L. A. A.; FERREIRA, F.; FERREIRA NETO, J. S.; GRISI-FILHO, J. H. H.; DIAS, R. A.; AMAKU, M.; TELLES, E. O.; HEINEMANN, M. B.; GONÇALVES,
V. S. P. Prevalence and herd-level risk factors of bovine tuberculosis in the State of Santa Catarina, Brazil. Semina: Ciências Agrárias, Londrina, v. 37, n. 5, p. 3659-3672, 2016. Suplemento 2.

VENDRAME, F. B.; AMAKU, M.; FERREIRA, F.; TELLES, E. O.; GRISI-FILHO, J. H. H.; GONÇALVES, V. S. P.; HEINEMANN, M. B.; FERREIRA NETO, J. S.; DIAS, R. A. Epidemiologic characterization of bovine tuberculosis in the State of Rondônia, Brazil. Semina: Ciências Agrárias, Londrina, v. 37, n. 5, p. 3639-3646, 2016. Suplemento 2.

WARDS, B. J.; COLLINS, D. M.; LISLE, G. W. Detection of Mycobacterium bovis in tissues by polymerase chain reaction. Veterinary Microbiology, Amsterdam, v. 43, n. 2-3, p. 227-240, 1995.

WARREN, R. M.; GEY van PITTIUS, N. C.; BARNARD, M.; HESSELING, A.; ENGELKE, E.; DE KOCK, M.; GUTIERREZ, M. C.; CHEGE, G. K.; VICTOR, T. C.; HOAL, E. G.; van HELDEN, P. D. Differentiation of Mycobacterium tuberculosis complex by PCR amplification of genomic regions of difference. International Journal of Tuberculosis and Lung Disease, Paris, v. 10, n. 7, p. 818-822, 2006.

\section{WORLD ORGANISATION FOR ANIMAL HEALTH}

- OIE. Bovine tuberculosis. In: Manual of diagnostics tests and vaccines for terrestrial animals. [S.1.: s.n.], 2009. v. 1, pt. 2, sec. 2.4, chap. 2.4.7. Available at: $\quad<$ http://www.oie.int/fileadmin/Home/eng/Health standards/tahm/2.04.07_BOVINE_TB.pdf $>$. Accessed at: 20 oct. 2015. 